\title{
Toxicity of herbicides on Escherichia coli growth
}

\author{
Botelho, RG. ${ }^{a *}$, Froes, CM. ${ }^{b}$ and Santos, JB. ${ }^{c}$ \\ aLaboratório de Ecotoxicologia Aquática, Centro de Energia Nuclear na Agricultura - CENA, \\ Universidade de São Paulo - USP, Av. Centenário, 303, CEP 13400-970, Piracicaba, SP, Brazil

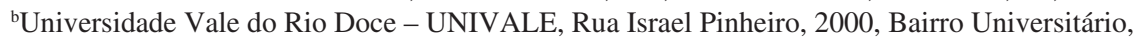 \\ CP 295, CEP 35020-220, Governador Valadares, MG, Brazil \\ 'Departamento de Agronomia, Universidade Federal dos Vales do Jequitinhonha e Mucuri - UFVJM, \\ Rod. MGT 367, Km 583, Campus JK, CEP 39100-000, Diamantina, MG, Brazil \\ *e-mail: rbotelhoccena@usp.br
}

Received October 5, 2010 - Accepted January 4, 2011 - Distributed February 29, 2012

(With 4 figures)

\begin{abstract}
Agriculture uses a huge variety and quantity of chemicals. If, on one hand, the goal is to increase productivity, on the other hand these products contaminate aquatic environments. Among these products, herbicides deserve greater attention in relation to contamination of aquatic environments due to their extensive use to weed control. This study was carried out because the effects of these molecules on aquatic microorganisms such as Escherichia coli, is still unclear. Using microdilution plate assays, Escherichia coli were exposed to various commercial formulations of herbicides widely used in Brazil. The herbicide paraquat was the only one able to prevent the growth of Escherichia coli and is characterized as bacteriostatic.
\end{abstract}

Keywords: aquatic ecosystem, bacteriostatic, paraquat.

\section{Toxicidade de herbicidas sobre o crescimento de Escherichia coli}

\section{Resumo}

A agricultura utiliza uma enorme variedade de produtos químicos, e se por um lado a meta é aumentar a produtividade, por outro lado estes produtos contaminam ambientes aquáticos. Entre estes produtos, herbicidas merecem maior atenção em relação à contaminação de ecossistemas aquáticos, devido a seu amplo emprego para controlar plantas daninhas. Este estudo foi realizado porque os efeitos destas moléculas em micro-organismos aquáticos, tais como Escherichia coli, ainda são pouco estudados. Através de ensaios de microdiluição, E. coli foi exposta a várias formulações comerciais de herbicidas amplamente utilizados no Brasil e foi verificado que o herbicida paraquat foi o único capaz de impedir o crescimento de E. coli, caracterizando-se assim como bacteriostático.

Palavras-chave: ecossistemas aquáticos, bacteriostático, paraquat.

\section{Introduction}

Aquatic ecosystems experience changes most often associated with industrial, urban and agricultural activities. Among these activities, the latter has been particularly responsible for more contamination to non-target organisms, both vertebrates and invertebrates (Mozeto and Zagatto, 2006). Thus, although pesticides fulfill the role of protecting crops from pests, diseases and weeds, increasing productivity, they pose risks to aquatic environments (Mozeto and Zagatto, 2006).

Herbicides are a heterogeneous category of chemical products especially synthesized for weed control, but they can reach aquatic ecosystems in several ways from the area where they are applied, reaching aquatic organisms (Tomita and Beyruth, 2002).
Aquatic organisms are exposed to these molecules simply by contact with water or sediment, and toxic effects may include both mortality and sublethal effects, such as changes in growth, development, reproduction, physiology, behavior and appearance of pathologies (Rand and Petrocelli, 1985).

Atrazine (2-chloro-4-ethylamino-6-isopropyl-amino1,3,5-triazine) and picloram (4-Amino-3,5,6-trichloro-2pyridinecarboxylic acid) herbicides are among the most used in Brazil agriculture. The first is especially recommended for crops of maize, sorghum, sugar cane, among others, and has high leaching potential (Rodrigues and Almeida, 2005). As for picloram, it is used in Brazilian pastures and is known for having high persistence in soil (Close et al., 
2003b; Berisford et al., 2006) low sorption, high water solubility and high leaching potential and can reach groundwater aquifers (Bovey and Richardson, 1991; Close et al., 2003a). Due to these characteristics, atrazine and pycloran are of great concern for aquatic ecosystems.

Historically, studies on the effects of such chemicals on aquatic life have focused on macroscopic organisms, with particular emphasis on vertebrates (for example, Poleksic and Karan, 1999; Sarikaya and Yilmaz, 2003; Botelho et al., 2009). However, bacteria represent important members of the fresh water flora and are presumably vulnerable to alterations in their growth and reproduction due to exposure to chemical contaminants (Higgins and Hohn, 2007).

Aquatic bacteria such as Escherichia coli are extremely important to the aquatic environment since they participate in the organic matter decomposition, nutrient cycling and energy flow (Bernhard et al., 2005). Although various studies have evaluated the toxicity promoted by pesticides to the environment using bacteria as a test organism, reports on the Escherichia coli use are minimal (Bálague et al., 2001; Higgins and Hohn, 2007).

In order to comprehend the effects of chemical agents on aquatic bacteria better, an experiment in vitro was carried out, where the toxicity of many common herbicides was evaluated using Escherichia coli as a test-organism.

\section{Material and Methods}

To evaluate herbicides effect on the growth of Escherichia coli the ATCC 25922 strain was used obtained from the Microbiology Laboratory at the University Vale do Rio Doce - UNIVALE. The herbicides were obtained from the Department of Agronomy at the University Vale do Rio Doce. The herbicide concentrations used in each well in this study were in mg/L: DMA (0.23), Agimix (0.10), Siptran, Atranex and Herbitrim (0.10), Fusilade (0.23), Gliz and Roundup (0.09), Dual (0.06), Fortex (0.232), MSMA (0.12), Gramoxone (0.08), Padron (0.03), Tordon (0.10), Combine (0.11) and Trifluralina (0.045). Some technical characteristics are shown in Table 1.

The definition of concentrations used was based on the commercially recommended dose taking into account the average lethal concentration (LC50) for aquatic wildlife (fishes) (Rodrigues and Almeida, 2005).

All herbicide solutions were prepared prior to their use, and were subsequently sterilized by filtration (Millipore filter, $0.22 \mathrm{~mm}$ ) in a laminar flow hood. The broth microdilution assay was done according to the National Committee for Clinical Laboratory Standards (NCCLS) M7-A6 (2003). Microdilution plates were used for inoculation and evaluation by adding $180 \mu \mathrm{L}$ BHI and inoculum broth and $20 \mu \mathrm{L}$ of each herbicide with three replicates each. Negative $(200 \mu \mathrm{L}$ $\mathrm{BHI}$ medium) and positive controls (bacteria $+200 \mu \mathrm{L} \mathrm{BHI}$ medium) were also used with three replicates.

After microdilution plate preparation, the bacterial population was incubated at $37^{\circ} \mathrm{C}$ and the colony forming units density (CFU) was measured by optical density at $655 \mathrm{~nm}$ on a spectrophotometer.

Growth curves were prepared from the relationship CFU and time in each herbicide tested. Specifically for the range between 120 and 210 minutes after incubation (exponential growth value for Escherichia coli, considering the control), linear equations were established to estimate the angular coefficient, relating CFU and time. These values and those obtained in 600 minutes reading from the original growth equations were analysed for variance and averages, when significant, were compared using the Tukey test at $5 \%$ probability.

Table 1. Technical information about herbicides suggested toxicity evaluation on non - target organisms.

\begin{tabular}{ccccc}
\hline $\begin{array}{c}\text { Commercial } \\
\text { product }\end{array}$ & Technical product & Chemical group & $\begin{array}{c}\text { Concentration of } \\
\text { technical product }\end{array}$ & $\begin{array}{c}\text { Concentration used } \\
\text { in this study (mg/L) }\end{array}$ \\
\hline DMA & $2,4-\mathrm{D}$ & Phenoacetic acid & $670 \mathrm{~g} / \mathrm{L}$ & 0.23 \\
Agimix & Alachlor + Atrazine & $\begin{array}{c}\text { Chloroacetanilide }+ \\
\text { Triazine }\end{array}$ & $260+260 \mathrm{~g} / \mathrm{L}$ & 0.10 \\
Siptran, Atranex & Atrazine & Triazine & 0.10 \\
and Herbitrim & Fluazifop p-butyl & Aryloxyphenoxy & $125 \mathrm{~g} / \mathrm{L}$ & 0.23 \\
Fusilade & propionate & 0.09 \\
Gliz and roundup & Glyfosate & Glicine derivate & $480 \mathrm{~g} / \mathrm{L}$ & 0.06 \\
original & S-metalachlor & Acetanilides & $960 \mathrm{~g} / \mathrm{L}$ & 0.232 \\
Dual & Msma + Diuron & Organoarsenic + Urea & $360+140 \mathrm{~g} / \mathrm{L}$ & 0.12 \\
Fortex & Msma & Organoarsenic & $720 \mathrm{~g} / \mathrm{L}$ & 0.08 \\
MSMA & Paraquat & Bypiridyls & $200 \mathrm{~g} / \mathrm{L}$ & 0.03 \\
Gramoxone & Picloran & Pyridinecarboxylic acid & $388 \mathrm{~g} / \mathrm{L}$ & 0.10 \\
Padron & Picloram + 2,4 - D & Picolinic and & $64+240 \mathrm{~g} / \mathrm{L}$ & 0.11 \\
Tordon & Phenoxyacetic acid & & 0.045 \\
Combine & Tebuthiuron & Urea derivate & $500 \mathrm{~g} / \mathrm{L}$ & $445 \mathrm{~g} / \mathrm{L}$ \\
Trifluralina & Trifluralin & Dinitroaniline & &
\end{tabular}




\section{Results}

The growth of Escherichia coli in the range between 100-300 minutes incubation was observed when exposed to the herbicides Agimix, Atranex, Herbitrin and Siptran (all with technical product atrazine). Regardless of herbicide, Escherichia coli growth was higher in the control treatment (free of herbicides) (Figure 1).

Comparing the toxicity of auxin mimicking herbicides, Escherichia coli were more sensitive to the Padron herbicide than to Tordon and DMA (Figure 2). Compared to the control, the Tordon herbicide promoted greater growth, unlike DMA and Padron herbicides.

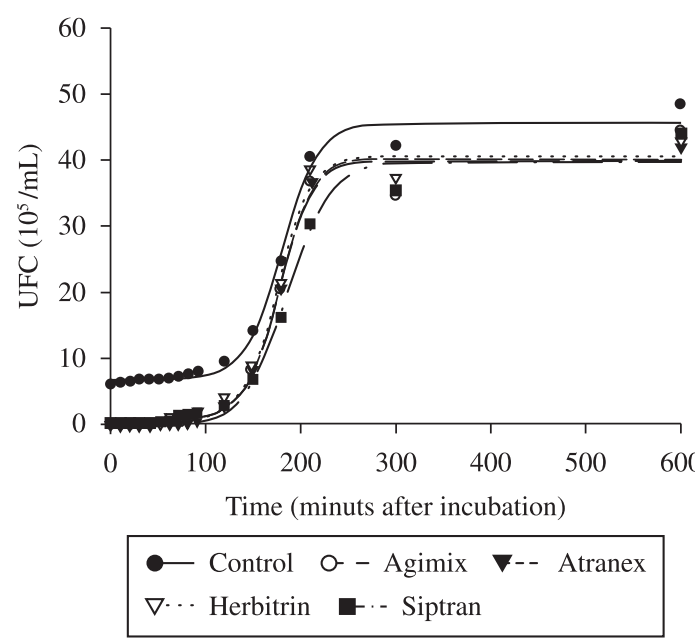

Figure 1. Escherichia coli growth under BHI containing different atrazine formulations, incubated for 600 minutes. Non-linear regressions tested by " $\mathrm{t}$ " at $5 \%$ of probability, with coefficient of determination higher than $90 \%$.

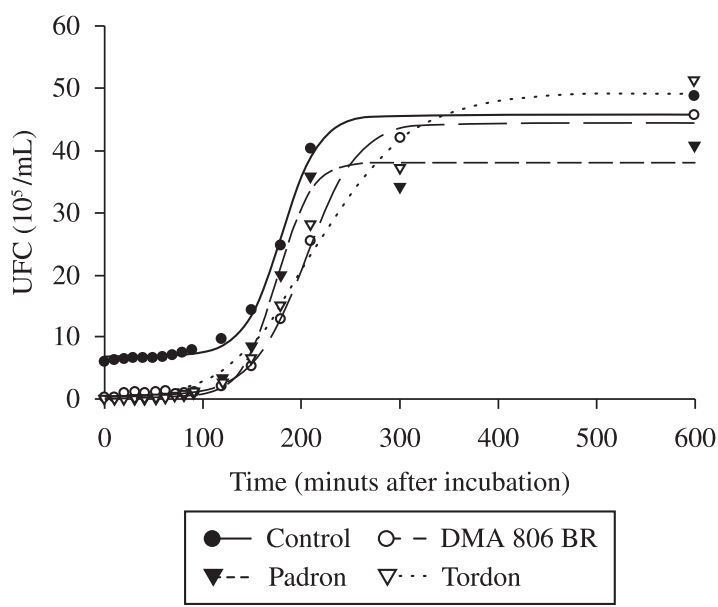

Figure 2. Escherichia coli growth under BHI containing DMA, Padron and Tordon (auxin mimicking herbicides), incubated for 600 minutes. Non-linear regressions tested by "t" at $5 \%$ of probability, with coefficient of determination higher than $90 \%$.
Regarding non-selective herbicides, recommended for plant desiccation, there is growth of Escherichia coli from 100 to approximately 320 minutes incubation when exposed to Roundup and Gliz. However, in relation to the Gramoxone herbicide, there was no bacterial growth during the first 300 minutes of incubation, showing extreme sensitivity of this organism to the product (Figure 3).

Among Dual, Fortex, Combine, Fusilade, MSMA and Trifluralin herbicides, it was observed that Escherichia coli has similar sensitivity to all these products. However, it was lower when compared to the control (Figure 4).

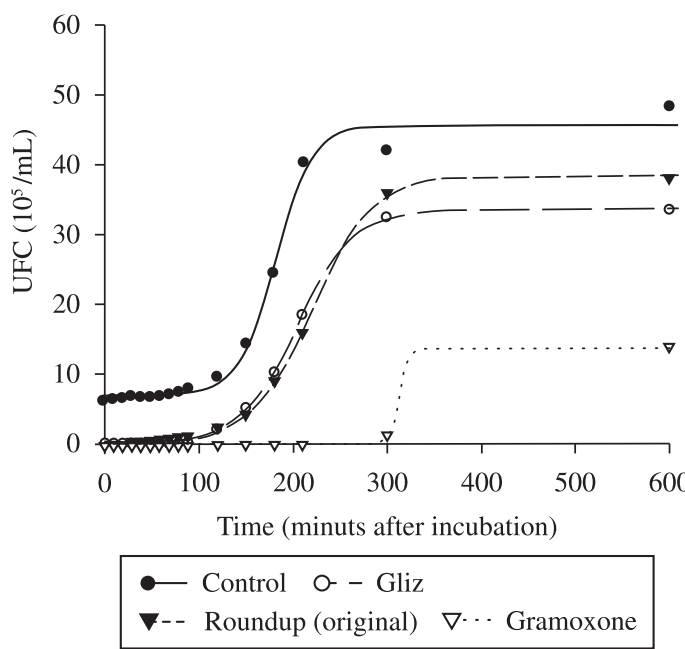

Figure 3. Escherichia coli growth under BHI containing Gliz, Roundup and Gramoxone, incubated for 600 minutes. Non-linear regressions tested by "t" at $5 \%$ of probability, with coefficient of determination superior to $90 \%$.

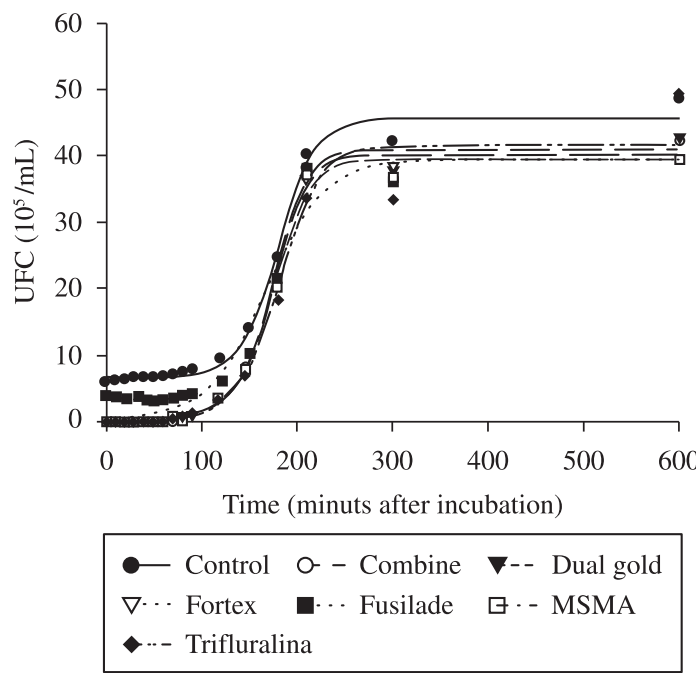

Figure 4. Escherichia coli growth under BHI containing different herbicide formulation, incubated for 600 minutes. Non-linear regressions tested by "t" at $5 \%$ of probability, with coefficient of determination higher than $90 \%$. 


\section{Discussion}

Considering the exponential growth phase of Escherichia coli (observed between approximately 120210 minutes in this work), it is possible to estimate the following decreasing scale of herbicide toxicity on Escherichia coli: Gramoxone> Roundup $=$ Gliz $>$ DMA $=$ Tordon $=$ Siptran $>$ Trifluralin $=$ Fusilade $=$ Padron $=$ Fortex $>$ MSMA $=$ Agimix $=$ Atranex $=$ Dual $=$ Herbitrim $=$ Combine $($ Table 2$)$. This relationship establishes the cell division intensity during the growth log phase.

After 600 minutes of incubation, the following decreasing scale herbicides toxicity on Escherichia coli based on the CFU number was established: Gramoxone $>$ Gliz $>$ Roundup $=$ Fusilade $=$ MSMA $=$ Fortex $=$ Padron $=$ Atranex $=$ Combine $=$ herbitrin $=$ Dual $=>$ Siptran $=$ Agimix $>$ DMA $>$ Tordon $=$ Trifluralin $($ Table 2). In this case, absolute values for the total CFU formed in each treatment were compared between each other.

The first bacterial growth phase is the lag phase, which according to Trabulsi and Alterthum (2008) is an adaptation period to the environment which they were exposed to, with intense metabolic activity and enzyme production that are prerequisites for their division. In this study, the lag phase corresponds to the period from 0 to 100 minutes incubation. It can be noted that there was no bacterial growth in the control treatment, suggesting faster adaptation as the medium was free of herbicides. After 100 minutes of adaptation, the bacterium started the log or exponential growth phase, characterized by cell multiplication. At this stage there is cell division at a maximum and constant speed reaching a point where there is lack of nutrients, and then the number of dividing cells becomes equal to the number of death cells (Trabulsi and Alterthum, 2008), then starting the stationary phase. All these three phases can be observed in Figures 1-4.

According to Finkel (2006) when bacterial isolates of environmental origin are successfully cultured in the laboratory, they tend to adhere to a model of growth that has been well characterized in the bacteriological literature, as mentioned above by Trabulsi and Alterthum (2008). According to this model, the period between the lag phase and nutrients depletion followed by bacterial death occurs in less than 24 hours for most coliform bacteria such as Escherichia coli. However, this could explain the difference between bacterial growth from 110 to 220 minutes and 600 minutes of exposure to the same herbicide. In this case, 110 to 220 minutes correspond to the stage in which bacteria are more active and thus at the height of its reproduction. By reaching the final period of exposure (600 minutes), slower growth can be observed due to cellular stress caused by intense multiplication in the previous phase.

Table 2. Values of Escherichia coli growth (estimated between 120 and 210 and at 600 minutes of incubation) in linear function with respective determination coefficient $\left(\mathrm{r}^{2}\right)$ and total number of colony-forming units $(\mathrm{CFU})$ at the end of incubation.

\begin{tabular}{|c|c|c|c|}
\hline $\begin{array}{c}\text { Herbicide } \\
\left(\text { commercial product }^{\circledR}\right)\end{array}$ & $\begin{array}{c}\text { Growth rate 120-210 minutes } \\
\text { after incubation (optical } \\
\text { density at } 655 \mathrm{~nm})\end{array}$ & $\begin{array}{l}\text { Coefficient of } \\
\text { determination }\end{array}$ & $\begin{array}{l}\text { CFU }\left(\times 10^{5}\right) \text { at the end of } \\
\text { incubation }(600 \text { minutes) } \\
(\text { optical density at } 655 \mathrm{~nm})\end{array}$ \\
\hline $\begin{array}{l}\text { Control } \\
\text { (without herbicide) }\end{array}$ & $0.3415^{\mathrm{b}}$ & 0.98 & $48.41^{\mathrm{a}}$ \\
\hline Agimix & $0.3786^{\mathrm{a}}$ & 0.97 & $44.07^{\mathrm{b}}$ \\
\hline Atranex & $0.3825^{\mathrm{a}}$ & 0.95 & $41.94^{\mathrm{bc}}$ \\
\hline Combine & $0.3928^{\mathrm{a}}$ & 0.96 & $42.16^{\mathrm{bc}}$ \\
\hline DMA & $0.2572^{\mathrm{c}}$ & 0.93 & $45.68^{\mathrm{ab}}$ \\
\hline Dual & $0.3830^{\mathrm{a}}$ & 0.95 & $42.88^{\mathrm{bc}}$ \\
\hline Fortex & $0.3680^{\mathrm{ab}}$ & 0.96 & $39.35^{\mathrm{c}}$ \\
\hline Fusilade & $0.3560^{\mathrm{b}}$ & 0.94 & $39.18^{\mathrm{c}}$ \\
\hline Gliz & $0.1823^{\mathrm{d}}$ & 0.95 & $33.40^{\mathrm{d}}$ \\
\hline Gramoxone & $0.0000^{\mathrm{e}}$ & 0.00 & $13.90^{\mathrm{e}}$ \\
\hline Herbitrin & $0.3867^{\mathrm{a}}$ & 0.95 & $42.67^{\mathrm{bc}}$ \\
\hline MSMA & $0.3778^{\mathrm{a}}$ & 0.95 & $39.22^{\mathrm{c}}$ \\
\hline Padron & $0.3655^{\mathrm{ab}}$ & 0.95 & $40.75^{\mathrm{bc}}$ \\
\hline Roundup & $0.1517^{\mathrm{d}}$ & 0.95 & $38.08^{\mathrm{c}}$ \\
\hline Siptran & $0.3054^{\mathrm{c}}$ & 0.94 & $43.86^{\mathrm{b}}$ \\
\hline Tordon & $0.2810^{c}$ & 0.95 & $51.29^{\mathrm{a}}$ \\
\hline Trifluralina & $0.3412^{b}$ & 0.95 & $49.00^{\mathrm{a}}$ \\
\hline C.V. $(\%)$ & 6.75 & 5.24 & 9.68 \\
\hline
\end{tabular}

Averages followed by letters equal in each colunm do not differ among themselves by Tukey (5\% of probability). 
Escherichia coli is routinely used as an indicator of water quality, however, its concentration can be influenced by stressors, which can inhibit (Collier et al., 1990; Bálague et al., 2001) or stimulate (Yurovskaya, 1975) its growth, as seen in this study.

In this study, Escherichia coli were not affected by atrazine concentrations. These same results were also found by Koutsotoli et al. (2005) and Higgins and Hohn (2007). In the work by Koutsotoli et al. (2005), the growth of NCTC 9001 Escherichia coli and Enterococcus faecalis was not affected by up to $0.1 \mathrm{mg} / \mathrm{L}$ atrazine concentrations. Higgins and Hohn (2007) also exposed Escherichia coli to atrazine concentrations and did not observe bacterial growth inhibition. In this study, the same atrazine concentration (in all commercial formulations) used in Koutsotoli et al. (2005) was applied (0.1 mg/L) and although authors have used different strains of Escherichia coli in these two studies, the herbicide was not toxic to their growth. In another study involving a commonly used herbicide, Bálague et al. (2001) reported abolition of $E$. coli growth at $2 \mathrm{~mm}$ concentration of 2,4-dichlorophenoxyacetic acid (2,4-D).

During the first 300 minutes, the paraquat herbicide (Gramoxone commercial formulation) did not allow bacterial growth. After this period, there is a reasonable exponential growth phase, indicating high toxicity of the product to Escherichia coli, however discarding the bactericidal action hypothesis. The number of CFU in the final period of incubation (600 minutes) was much lower compared to other herbicides, suggesting a high toxicity of this product for this bacterium, especially in 300 minutes exposure.

In Escherichia coli, paraquat has been reported as a bacteriostatic agent (Davison and Papirmeister, 1971) and this information was confirmed in our study. Farrington et al. (1973) demonstrated that this product reacts rapidly with molecular oxygen generating the toxic radical $\left(\mathrm{O}_{2}-\right)$. The enzymatic antioxidant defenses are fundamental to reverse such toxicity and thus the superoxide dismutase enzyme acts on the $\mathrm{O}_{2}$ - dismuting it into hydrogen peroxide $\left(\mathrm{H}_{2} \mathrm{O}_{2}\right)$ and water $\left(\mathrm{H}_{2} \mathrm{O}\right)$. As the hydrogen peroxide $\left(\mathrm{H}_{2} \mathrm{O}_{2}\right)$ is also toxic to biological systems, catalysis, another important antioxidant enzyme, promotes the dissociation of this compound into $\mathrm{H}_{2} \mathrm{O}+\mathrm{O}_{2}$ (Halliwell and Gutteridge, 2002) and thus paraquat toxicity ceases to exist. The complete bacterial growth inhibition by paraquat action in the first 300 minutes may be due to the $\mathrm{O}_{2}$-toxic effect. After this period, antioxidant enzymes may have eliminated part of the toxicity and then bacterial growth was observed.

In conclusion, our data suggest that with the exception of paraquat, all herbicides may not influence bacterial replication.

Acknowledgements - We are grateful to the Fundação de Amparo a Pesquisa do Estado de Minas Gerais (FAPEMIG) and Conselho Nacional de Desenvolvimento Científico e Tecnológico $(\mathrm{CNPq})$ for the financial support.

\section{References}

BÁLAGUE, C., STURTZ, N., DUFFARD, R. and EVANGELISTA DE DUFFARD, AM., 2001. Effect of 2,4-dichlophenoxacetic acid herbicide on Escherichia coli growth, chemical composition and cellular envelope. Environmental Toxicology, vol. 16, no. 1, p. 4353. http://dx.doi.org/10.1002/1522-7278(2001)16:1\%3C43::AIDTOX50\%3E3.0.CO;2-R

BENHARD, AE., COLBERT, D., MCMANUS, J. and FIELD, KG., 2005. Microbial community dynamics based on 16S rRNA gene profiles in a Pacific Northwest estuary and its tributaries. Microbial escology, vol. 52, p. 115-128.

BERISFORD, YC., BUSH, PB. and TAYLOR JUNIOR, JW., 2006. Leaching and persistence of herbicides for kudzu (Pueraria montana) control on pine regeneration sites. Weed Sciense, vol. 54, p. 391-400.

BOTELHO, RG., SANTOS, JB., OLIVEIRA, TA., BRAGA, RR. and BYRRO, ECM., 2009. Toxicidade aguda de herbicidas à Tilápia (Oreochromis niloticus). Planta Daninha, vol. 27, no. 3, p. 621-626.

BOVEY, RW. and RICHARDSON, CW., 1991. Dissipation of clopyralid and picloram in soil and seep flow in the blacklands of Texas. Journal of Environmental Quality, vol. 20, p. 528-531. http://dx.doi.org/10.2134/jeq1991.00472425002000030005x

CLOSE, ME., MAGESAN, GN., LEE, R., STEWART, MK. and HADFIELD, JC., 2003b Field study of pesticide leaching in an allophonic soil in New Zealand. 1: Experimental results. Australian Journal of Soil Research, vol. 41, p. 825-846. http:// dx.doi.org/10.1071/SR02081

CLOSE, ME., PANG, L., MAGESAN, GN., LEE R. and GREEN, SR., 2003a. Field study of pesticide leaching in an allophonic soil in New Zealand. 1: Experimental results. Australian Journal of Soil Research, vol. 41, p. 809-824. http://dx.doi.org/10.1071/SR02080

COLLIER, PJ., RAMSEY, AJ., AUSTIN, P. and GILBERT, P., 1990. Growth inhibitory and biocidal activity of some isothiasolone biocides. Journal of Applied Bacteriology, vol. 69, no. 4 , p. $569-577$.

DAVISON, CL. and PAPIRMEISTER, B., 1971. Bacteriostasis of Escherichia coli by the herbicide paraquat. Proceedings of the Society for Experimental Biology and Medicine, vol. 136, no. 2, p. 359-364.

FARRINGTON, JA., EBERT, M., LAND, EJ. and FLETCHER, K., 1973. Bipyridylium quaternary salts and related compounds. V. pulses radiolysis studies of the reaction of paraquat radical with oxygen. Implications for the mode of action of bipyridyl herbicides. Biochimica et Biophysica Acta, vol. 314, no. 3, p. 372381. http://dx.doi.org/10.1016/0005-2728(73)90121-7

FINKEL, SE., 2006. Long-term survival during stationary phase: evolution and the GASP phenotype. Nature Reviews Microbiology, Vol. 4, p. 113-120. http://dx.doi.org/10.1038/nrmicro1340

HALLIWELL, B. and GUTTERIDGE, JMC., 2002. Free Radicals in Biology and Medicine. 3nd ed. Nova York: Oxford University Press. 936 p.

HIGGINS, J. and HOHN, C., 2007. Effects of prevalent freshwater chemical contaminants on in vitro growth of Escherichia coli and Klebsiella pneumoniae. Environmental Pollution, vol. 152, no. 2, p. 259-266. PMid:17681655. http://dx.doi.org/10.1016/j. envpol.2007.06.049 
KOUTSOTOLI, AD., DIMOU, DS., ALAMANOS, YP. and MAIPA, VE., 2005. Inductive effects of environmental concentration of atrazine on Escherichia coli and Enteroccocus faecalis. Folia Microbiologica, vol. 50, no. 4, p. 283-287. PMid:16408845. http://dx.doi.org/10.1007/BF02931407

MOZETO, AA. and ZAGATTO, PA., 2006. Ecotoxicologia aquática - Princípios e Aplicações. In ZAGATTO, PA. and BERTOLETTI, E. Introdução de agentes químicos no ambiente. São Carlos: Rima Editora. p. 15-38.

National Committee for Clinical Laboratory Standard, 2003. Methods for Dilution Antimicrobial Susceptibility Tests for Bacteria That Grow Aerobically, Approved Standard - M7-A6. 6nd ed. Clinical and Laboratory Standars Institute. vol. 23.

POLEKSIC, V. and KARAN, V., 1999. Effects of Trifluralin on Carp: Biochemical and Histological Evaluation. Ecotoxicology and Environmental Safety, vol. 43, no. 2, p. 213-221. PMid:10375424. http://dx.doi.org/10.1006/eesa.1999.1790
RAND, GM. and PETROCELLI, SR., 1985. Fundamentals of aquatic toxicology. Washington: Publishing Hemisphere. 665 p.

RODRIGUES, BN. and ALMEIDA, FS., 2005. Guia de herbicidas. 5nd ed. Londrina: Grarfmake. 591 p.

SARIKAYA, R. and YILMAZ, M., 2003. Investigation of acute toxicity and the effect of 2,4-D (2,4-dichlorophenoxyacetic acid) herbicide on the behavior of the common carp (Cyprinus carpio L., 1758; Pisces, Cyprinidae). Chemosphere, vol. 52, no. 1, p. 195-201. http://dx.doi.org/10.1016/S0045-6535(03)00106-1

TOMITA, RY. and BEYRUTH, Z., 2002. Toxicologia de agrotóxicos em ambiente aquático. Biológico, vol. 64, no. 2, p. 135-142.

TRABULSI, LR. and ALTERTHUM, F., 2008. Microbiologia. 5nd ed. São Paulo: Atheneu. 760 p.

YUROVSKAYA, EM., 1975. Behavior and indication value of some microorganisms under conditions of soil contamination by pesticides. Journal of hygiene, Epidemiology, Microbiology and Immunology, vol. 19, no. 1, p. 10-16. PMid:805171. 